\title{
Relative Contributions of Mg Hydration and Molecular Structural Restraints to the Barrier of Dolomite Crystallization: A Comparison of Aqueous and Non-Aqueous Crystallization in $(\mathrm{BaMg}) \mathrm{CO}_{3}$ and $(\mathrm{CaMg}) \mathrm{CO}_{3}$ Systems
}

\author{
Shi Zhou, Yuebo Wang and Henry Teng *
}

Citation: Zhou, S.; Wang, Y.; Teng, H. Relative Contributions of $\mathrm{Mg}$ Hydration and Molecular Structural Restraints to the Barrier of Dolomite Crystallization: A Comparison of Aqueous and Non-Aqueous Crystallization in (BaMg) $\mathrm{CO}_{3}$ and (CaMg) $\mathrm{CO}_{3}$ Systems. Minerals 2021, 11, 1214. https://doi.org/10.3390/ $\min 11111214$

Academic Editors: Carlos M. Pina and Carlos Pimentel

Received: 7 September 2021

Accepted: 22 October 2021

Published: 30 October 2021

Publisher's Note: MDPI stays neutral with regard to jurisdictional claims in published maps and institutional affiliations.

Copyright: (c) 2021 by the authors. Licensee MDPI, Basel, Switzerland. This article is an open access article distributed under the terms and conditions of the Creative Commons Attribution (CC BY) license (https:/ / creativecommons.org/licenses/by/ $4.0 /)$.
School of Earth System Science, Tianjin University, Tianjin 300072, China; tjuzhoushi@gmail.com (S.Z.); wangyuebo@tju.edu.cn (Y.W.)

* Correspondence: huihenry.teng@tju.edu.cn or hteng@gwu.edu
Abstract: Carbonate mineralization is reasonably well-understood in the $\mathrm{Ca}-\mathrm{CO}_{2}-\mathrm{H}_{2} \mathrm{O}$ system but continuously poses difficulties to grasp when $\mathrm{Mg}$ is present. One of the outstanding questions is the lack of success in dolomite $\mathrm{MgCa}\left(\mathrm{CO}_{3}\right)_{2}$ crystallization at atmospheric conditions. The conventional view holds that hydration retards the reactivity of $\mathrm{Mg}^{2+}$ and is supported by solvation shell chemistry. This theory however is at odds with the easy formation of norsethite $\mathrm{MgBa}\left(\mathrm{CO}_{3}\right)_{2}$, a structural analogue of dolomite, leading to the premise that crystal or molecular structural constrains may also be at play. The present study represents our attempts to evaluate the separate contributions of the two barriers. Crystallization in the $\mathrm{Mg}-\mathrm{Ba}-\mathrm{CO}_{2}$ system was examined in a non-aqueous environment and in $\mathrm{H}_{2} \mathrm{O}$ to isolate the effect of hydration by determining the minimal relative abundance of $\mathrm{Mg}$ required for norsethite formation. The results, showing an increase from 1:5 to 6:4 in the solution $\mathrm{Mg} / \mathrm{Ba}$ ratio, represented a $\sim 88 \%$ reduction in $\mathrm{Mg}^{2+}$ reactivity, presumably due to the hydration effect. Further analyses in the context of transition state theory indicated that the decreased $\mathrm{Mg}^{2+}$ reactivity in aqueous solutions was equivalent to an approximately $5 \mathrm{~kJ} / \mathrm{mol}$ energy penalty for the formation of the activated complex. Assuming the inability of dolomite to crystallizes in aqueous solutions originates from the $\sim 40 \mathrm{~kJ} / \mathrm{mol}$ higher (relative to norsethite) Gibbs energy of formation for the activated complex, a hydration effect was estimated to account for $\sim 12 \%$ of the energy barrier. The analyses present here may be simplistic but nevertheless consistent with the available thermodynamic data that show the activated complex of dolomite crystallization reaction is entropically favored in comparison with that of norsethite formation but is significantly less stable due to the weak chemical bonding state.

Keywords: norsethite; dolomite; transition state theory; activated complex; crystallization barrier; hydration

\section{Introduction}

Interests in carbonates trace back to 1870s, with the first recognition that $\mathrm{CaCO}_{3}$ may form different polymorphs [1]. Since then, our knowledge base in this field has expanded immensely in virtually all fronts of related areas, first in crystallography [2,3] and mineralogy [4,5], followed by crystallization/dissolution as well as mineral-water interfacial reactions [6-11]. Modern-time motivation to study carbonates lies chiefly in the need to understand biomineralization [12] and the unique chemistry of mineral crystallization and dissolution where the thermodynamic equilibria between $\mathrm{CO}_{2}(\mathrm{~g}), \mathrm{HCO}_{3}{ }^{-}$and $\mathrm{CO}_{3}=(\mathrm{aq})$, and alkali earth metals control long-term climate $[13,14]$. To date, significance advances have revealed various physiochemical aspects of carbonate behavior and reactivity, both in geological and biological settings.

Looking at carbonate minerals in the Earth's crust as a whole, however, one cannot help but notice the puzzling question of dolomite mineralization [15]. Despite belonging 
to the same crystal system (trigonal/rhombohedral) as calcite $\mathrm{CaCO}_{3}$ (the most wellstudied member of carbonate minerals) and composing $~ 50 \%$ of the world carbonate formations [16], dolomite $\mathrm{MgCa}\left(\mathrm{CO}_{3}\right)_{2}$ has not been shown to crystallize in inorganic systems at ambient conditions. Dolomite is constructed in a highly ordered structure where not only do the cations and anions separate themselves into individual layers along the $c$-axis but the two cations, $\mathrm{Ca}^{2+}$ and $\mathrm{Mg}^{2+}$, also alternate instead of forming mixed layers. Additionally, rather than taking a uniform orientation, the planar $\mathrm{CO}_{3}{ }^{2-}$ units are situated perpendicularly to the $c$ direction and rotate $60^{\circ}$ around the axis in each successive layer. Dolomite $(R \overline{3})$ differs from calcite $(R \overline{3} c)$ only in the absence of the $c$-glide plane because of the alternation of cation layers along the $c$-axis. Intuitively, the resemblance and similarity between the element $\mathrm{Ca}$ and $\mathrm{Mg}$ (alkaline earth metals in adjacent periods) may indicate that the formation of dolomite can be simply executed by $\mathrm{Mg}$ partially replacing $\mathrm{Ca}$ in calcite. The experimental tests thus far however have shown that this conjecture is nowhere close to reality.

The difficulty to incorporate $\mathrm{Mg}$ into the calcite structure at ambient conditions is overwhelmingly attributed to the stronger (relative to $\mathrm{Ca}^{2+}$ ) hydration of $\mathrm{Mg}^{2+}$ ions [17-20]. The rationale for this reasoning is the heightened charge density of the $\mathrm{Mg}^{2+}$ ion originating from the cation's smaller size (ionic radius $0.72 \AA$ ) relative to $\mathrm{Ca}^{2+}$ [21]. Assuming a spherical geometry, the charges per surface area on magnesium cations are thus nearly twice of that on calcium cations. A high surface charge density can lead to a substantial charge transfer from ions to solvent, resulting in reduced reactivity of the ions. For magnesium, the net charge on the central $\mathrm{Mg}^{2+}$ of $\mathrm{Mg}\left[\mathrm{H}_{2} \mathrm{O}_{6}{ }^{2+}\right.$ was calculated to be only 1.18 [15]. In addition, the hydration energy for $\mathrm{Mg}^{2+}$ is estimated at about $\sim 30 \%$ greater than that for $\mathrm{Ca}^{2+}$ [22-28], indicating indeed a lower reactivity of $\mathrm{Mg}^{2+}$ in an aqueous environment.

Oddly, the cation hydration retardation theory does not seem to offer valid predictions when applied to siderite $\left(\mathrm{FeCO}_{3}, R \overline{3} \mathrm{c}\right)$. Using the same arguments for the lack of magnesite $\mathrm{MgCO}_{3}$ formation at atmospheric conditions, the model is set to predict that the ferrous carbonate phase is at least equally difficult to crystallize in ambient aqueous solutions given that $\mathrm{Fe}^{2+}$ has a similar size (0.61 0.78 $\AA$ depending on the spin state) and a slightly higher $(\sim 7 \%)$ hydration energy in comparison with $\mathrm{Mg}^{2+}$. However, it is well-known [29] that siderite mineralizes frequently at surface conditions, such as in the scale layers on steel pipes in industrial settings related to oil and gas production and transportation. More critically, direct tests of magnesite crystallization in the absence of water (i.e., non-aqueous $\mathrm{Mg}^{2+}$ solvation) have not supported the $\mathrm{Mg}$ hydration theory. Crucially insightful data with regard to the non-aqueous synthesis of $\mathrm{MgCO}_{3}$ was first provided by a century-old study where Neuberg and Rewald [30] examined the interactions of $\mathrm{CO}_{2}$ gas with $\mathrm{CaO}$ and $\mathrm{MgO}$ in methanolic suspensions. In the case of $\mathrm{CaO}$, a gel-like compound was obtained and subsequently identified as calcite. For the $\mathrm{MgO}$ experiment, no solid product was observed in the end. A more recent study [31] at settings slightly different (higher T and $\mathrm{P}$ at $50-70{ }^{\circ} \mathrm{C}$ and 3 bar $\mathrm{pCO}_{2}$ ) from those used by Neuberg and Rewald obtained an anhydrous magnesium carbonate precipitate but only found to be nano-aggregates of amorphous $\mathrm{MgCO}_{3}$. In light of the hydration retardation theory's implication that magnesite (and dolomite) should crystallize if the hydration shell around $\mathrm{Mg}^{2+}$ is breached or weakened, these results seem to strongly contradict the assumed hydration effect as all of the syntheses were performed in the absence of water.

An even more intriguing case inconsistent with the $\mathrm{Mg}$ hydration retardation theory is the binary carbonate mineral norsethite $\mathrm{MgBa}\left(\mathrm{CO}_{3}\right)_{2}[32,33]$. Other than the size difference between the cation pairs of $\mathrm{Mg}$ vs. $\mathrm{Ba}(\sim 0.8 \AA)$ and $\mathrm{Mg}$ vs. Ca $(\sim 0.3 \AA)$, norsethite is very similar to dolomite structure-wise, with the main distinction being that the orientations of the carbonate groups are more flexible instead of strictly fixed to a $60^{\circ}$ rotation in adjacent layers [33]. Owing to this difference, norstethite may not be considered a true isotypic analogue of dolomite in a strict sense but, nonetheless, has a similar stacking order in the $c$ direction with regard to cation-anion and cation-cation relationships. What is paradoxical is that, while dolomite has not been crystallized at atmospheric conditions thus 
far, norsethite can precipitate readily in a room temperature aqueous environment [34-36]. Although the results from a number of recent studies [37-42] indicated that the reaction pathway may involve dissolution-recrystallization of certain precursors, the routineness of norsethite formation clearly demonstrates that $\mathrm{Mg}^{2+}$ can dehydrate efficiently to enter the lattice of anhydrous carbonate crystals at ambient conditions. More importantly, the relative cation size ( $\mathrm{Mg}$ to $\mathrm{Ba}$ vs. $\mathrm{Mg}$ to $\mathrm{Ca}$ ) and the anion orientation are all structural factors, and the mere fact that a change in such parameters can result in the crystallization of ordered binary magnesium carbonate $\mathrm{MgBa}\left(\mathrm{CO}_{3}\right)_{2}$ argue strongly for a more important role of atomic arrangement along the reaction coordinate of dolomite formation, aside from $\mathrm{Mg}$ hydration. We suspect the aspect of structural restraints may lie chiefly in the transition state of the crystallization reactions because the Gibbs energy of formation for dolomite $(-2148.90 \mathrm{~kJ} / \mathrm{mol})[43]$ and norsethite $(-2167 \pm 2 \mathrm{~kJ} / \mathrm{mol})[40]$ is not significantly different. The goal of this study is to test this hypothesis and to assess the relative weight of $\mathrm{Mg}$ hydration and the structural limitation. We carry out crystallization experiments in $\mathrm{H}_{2} \mathrm{O}$ solutions and a non-aqueous solvent to determine the minimal relative abundance of $\mathrm{Mg}$ needed to form norsethite and use the difference in the determined minima to estimate the magnitude of the hydration effect. We then apply the transition state theory (TST) to further evaluate the contribution of $\mathrm{Mg}$ hydration to the reduction in the activated complex. Finally, we compare the $\mathrm{Mg}$ hydration effect and the activation free energy of dolomite crystallization to gauge the approximate scale of the structural restraints in the overall reaction process.

\section{Methods}

\subsection{Crystallization Experiments}

Aqueous stock solutions were prepared from $\mathrm{BaCl}_{2}, \mathrm{MgCl}_{2}$, and $\mathrm{NaHCO}_{3}$ using distilled deionized water. Chloride solutions containing 1, 10, 40, and $50 \mathrm{mM} / \mathrm{L}$ of metal ions were prepared first for $\mathrm{Mg}$ and Ba separately, followed by mixing varied proportions of the $\mathrm{MgCl}_{2}$ and $\mathrm{BaCl}_{2}$ solutions to achieve the desired levels of the $\mathrm{Mg}$-to-Ba ratio $(\mathrm{Mg} / \mathrm{Ba}$, from 4:6 to 9:1). The concentration of sodium bicarbonate solution varied from 5 to $250 \mathrm{mM}$. In a typical synthesis experiment, $20 \mathrm{~mL}$ of $\mathrm{NaHCO}_{3}$ solution were slowly titrated into $20 \mathrm{~mL}$ of a mixed cation chloride solution, sealed, and left still for ten days. Speciation, ionic activities, and supersaturation states of each experimental solution were calculated via the computer code PHREEQC. The solubility product for witherite and norsethite were assumed to be $\mathrm{K}_{\mathrm{sp}, \mathrm{wt}}=10^{-8.56}$ (PHREEQC database) and $\mathrm{K}_{\mathrm{sp}, \mathrm{nr}}=10^{-17.73}$ [40].

Non-aqueous experiments were carried out in formamide $\left(\mathrm{O}=\mathrm{CH}-\mathrm{NH}_{2}, \mathrm{FMD}\right)$ that has a weaker (relative to $\mathrm{H}_{2} \mathrm{O}$ ) autoionization (autoprotolysis constant $10^{-16}$ vs. $10^{-14}$ ) but a stronger polarity (dielectric constant 109 vs. 78) [44] and can dissolve inorganic salt easily to make experimental solutions. Stock solutions of $0.2 \mathrm{M} \mathrm{MgCl}_{2}, 0.2 \mathrm{M} \mathrm{BaCl}_{2}$, and $0.2 \mathrm{Cs}_{2} \mathrm{CO}_{3}$ were prepared by dissolving the corresponding salt compounds that were pre-dried in an oven at $60^{\circ} \mathrm{C}$. The experimental solutions with varied $\mathrm{Mg} / \mathrm{Ba}$ content (5:1, 2:1, 1:1, 1:2, and 1:5) were then made by mixing that of $\mathrm{MgCl}_{2}$ and $\mathrm{BaCl}_{2}$ in desired proportion, followed by slow titration into the $\mathrm{Cs}_{2} \mathrm{CO}_{3}$ stock. The final solution was kept closed and still for $24 \mathrm{~h}$.

All experiments were conducted at room temperature $\left(25 \pm 1{ }^{\circ} \mathrm{C}\right)$. At the end of crystallization experiments, individual solutions were centrifuged $(10,000 \mathrm{rpm}, 10 \mathrm{~min})$ and the solid was collected; washed extensively in ethanol to remove the residual $\mathrm{Na}^{+}$, $\mathrm{Cs}^{+}$, and $\mathrm{Cl}^{-}$; and oven-dried at below $30^{\circ} \mathrm{C}$. Chemicals and solvent used in the synthesis experiments were of analytical grade and purchased from Shanghai Aladdin Bio-Chem Technology Co.

\subsection{Precipitate Identification}

The crystallinity and mineral composition of the precipitates were characterized by powder X-ray diffraction (XRD) using a Riguka MiniFlex 600 instrument $\left(\mathrm{Cu} \mathrm{K}_{\alpha 1}\right.$ radiation). The diffractograms were collected from $3-70^{\circ}$ with a scanning rate of $2^{\circ} / \mathrm{min}$. Prior to 
instrumental analysis, the precipitates were dispersed in alcohol and pipetted on a zerobackground monocrystalline silicon sample holder and placed into the diffractometer once dried. The diffractograms were analyzed using the package of MDI Jade 6. Other than XRD characterization, the precipitates were not checked for impurity contents of $\mathrm{Na}, \mathrm{Cs}$, and $\mathrm{Cl}$ through chemical analyses.

\section{Results}

A total of 82 synthesis experiments (Table 1) were carried out in aqueous solutions with various combinations of supersaturation, cation-to-anion ratio $\left([\mathrm{Mg}+\mathrm{Ba}] / \mathrm{CO}_{3}\right)$, and relative concentrations of $\mathrm{Mg}$ to $\mathrm{Ba}(\mathrm{Mg} / \mathrm{Ba})$. All experiments were performed in supersaturated solutions with reference to norsethite $\left(0.3<\log \Omega_{\mathrm{N}}<5.46\right.$, where $\Omega_{\mathrm{N}}$ is the ratio of ionic activity product to the solubility product of norsethite), with all but six of them undersaturated with respect to witherite $\left(-0.63<\log \Omega_{\mathrm{W}}<2.33\right)$. Altogether, crystal formation was observed in 74 of the experimental runs (Table 1), of which 26 exhibited XRD signals of norsethite crystallization. The experiments that did not show crystallization either had low supersaturation with respect to norsethite $\left(\log \Omega_{\mathrm{N}}<1\right)$ and undersaturation to witherite or had a high level of $\mathrm{Mg}$ presence $(\mathrm{Mg}: \mathrm{Ba}>7: 3$ ) but low supersaturation relative to witherite $\left(\log \Omega_{\mathrm{W}}<0.4\right)$.

Exclusive formation of norsethite required a strong presence of $\mathrm{Mg}(\mathrm{Mg} / \mathrm{Ba}>7 / 3)$; decreasing $\mathrm{Mg}$ usually led to co-precipitation of norsethite and witherite first, followed by sole occurrence of witherite (Figure 1). The minimal requirement of $\mathrm{Mg} / \mathrm{Ba}$ for norsethite to be a component of the crystallization product was $6 / 4$, and this value appeared to be positively correlated with $\Omega_{\mathrm{N}}$ and the cation-to-anion ratio in the experimental solutions. For example, at $\log \Omega_{\mathrm{N}} \approx 2$ to 2.5 and cation/anion $\approx 0.28$, norsethite crystallized along with witherite in solutions with $\mathrm{Mg}: \mathrm{Ba}=6: 4$; when $\log \Omega_{\mathrm{N}}$ increased to approximately 5-5.5 and cation/anion $\approx 21-22$, norsethite was only detected at the conditions of $\mathrm{Mg}: \mathrm{Ba}=8: 2$. On the other hand, the exclusion of norsethite from crystallization (i.e., witherite was the sole product) could occur at any level of $\mathrm{Mg} / \mathrm{Ba}$ and any supersaturation (with respect to both norsethite and witherite) as long as the cation-to-anion ratio was sufficiently large (usually $>80 \sim 100$ ). For example, at $\log \Omega_{\mathrm{N}} \approx 2.2$ to 2.7 and cation/anion $\approx 130-140$, witherite was the only phase found in solution at $\log \Omega_{\mathrm{W}} \approx 0.3-1.0$, same as the experiments where $\log \Omega_{\mathrm{N}} \approx 4.0-4.5$, cation/anion $\approx 161-177$, and $\log \Omega_{\mathrm{W}} \approx 1.2-1.8$.

A much simpler outcome was observed in formamide containing varied amounts of $\mathrm{Mg}^{2+}$ and $\mathrm{Ba}^{2+}$ at a fixed concentration of $([\mathrm{Mg}]+[\mathrm{Ba}])$. Unlike the results in aqueous environment where norsethite formation required $\mathrm{Mg}$ dominated solution chemistry and in fact was never observed once $\mathrm{Mg} / \mathrm{Ba}<6 / 4$, norsthite was shown to be a major component of the precipitate at $\mathrm{Mg}: \mathrm{Ba}=1: 2$ along with witherirte and the single solid phase at $\mathrm{Mg} / \mathrm{Ba}=1$ (Figure 2). Similar to the observations in $\mathrm{H}_{2} \mathrm{O}$, a reduction in the relative abundance of $\mathrm{Mg}$ suppressed norsethite crystallization and ultimately led to a dominant occurrence of witherite at $\mathrm{Mg} / \mathrm{Ba}=1 / 5$ (Figure 2, traces of norsethite still visible). Different from aqueous experiments, however, a strong $\mathrm{Mg}$ presence with $\mathrm{Mg} / \mathrm{Ba}=2$ and 5 in FMD did not promote norsethite crystallization but instead led to the formation of an amorphous phase in both cases (Figures 2 and 3). The amorphous precipitate appeared as nano-aggregate (Figure 3 upper) of particulate constituents with approximately uniform sizes of $<10 \mathrm{~nm}$ (Figure 3 upper). In contrast, the crystalline phases (Figure 3 middle and lower) exhibited a conglomerate form with individual crystals of 20-100 nm in size (Figure 3 middle and lower). 
Table 1. Solution chemistry and mineral composition of aqueous synthesis experiments (SI $\mathrm{nrs}_{\text {s }}$ and $\mathrm{SI}_{\mathrm{wit}}$ : saturation Index with respect to norsethite $(\mathrm{N})$ and witherite $(\mathrm{W}) ; \mathrm{Mg} / \mathrm{Ba}$ : activity ratio $\mathrm{aMg}^{2+} / \mathrm{aBa}^{2+}$; np: no precipitation).

\begin{tabular}{|c|c|c|c|c|c|c|c|c|}
\hline $\begin{array}{c}(\mathrm{Mg}, \mathrm{Ba}) \mathrm{Cl}_{2} \\
{[\mathrm{M}]}\end{array}$ & $\begin{array}{c}\mathrm{NaHCO}_{3} \\
{[\mathrm{M}]}\end{array}$ & $\mathrm{Mg} / \mathrm{Ba}$ & $S I_{\text {nrs }}$ & $S I_{\text {wit }}$ & $\begin{array}{l}\mathrm{aMg}^{2+} \\
{[\mathrm{mM}]}\end{array}$ & $\begin{array}{l}\mathrm{aBa}^{2+} \\
{[\mathrm{mM}]}\end{array}$ & $\begin{array}{c}\mathrm{aCO}_{3}{ }^{2-} \\
{[\mathrm{mM}]}\end{array}$ & $\begin{array}{c}\text { Mineral } \\
\text { Phase }\end{array}$ \\
\hline \multirow{25}{*}{0.001} & \multirow{5}{*}{0.25} & $9: 1$ & 2.03 & 0.24 & 0.103 & 0.012 & 0.405 & $\mathrm{~N}$ \\
\hline & & $8: 2$ & 2.28 & 0.54 & 0.092 & 0.023 & 0.406 & $\mathrm{~N}$ \\
\hline & & $7: 3$ & 2.4 & 0.71 & 0.080 & 0.035 & 0.406 & $\mathrm{~N}$ \\
\hline & & $6: 4$ & 2.45 & 0.84 & 0.069 & 0.047 & 0.406 & $\mathrm{~W}+\mathrm{N}$ \\
\hline & & $5: 5$ & 2.47 & 0.94 & 0.058 & 0.059 & 0.406 & W \\
\hline & \multirow{5}{*}{0.1} & $9: 1$ & 1.88 & 0.16 & 0.158 & 0.018 & 0.225 & $\mathrm{~N}$ \\
\hline & & $8: 2$ & 2.13 & 0.47 & 0.140 & 0.036 & 0.225 & $\mathrm{~N}$ \\
\hline & & $7: 3$ & 2.25 & 0.64 & 0.123 & 0.054 & 0.225 & $\mathrm{~N}+\mathrm{W}$ \\
\hline & & $6: 4$ & 2.31 & 0.77 & 0.105 & 0.072 & 0.226 & W \\
\hline & & $5: 5$ & 2.33 & 0.87 & 0.088 & 0.089 & 0.226 & W \\
\hline & \multirow{5}{*}{0.05} & $9: 1$ & 1.66 & 0.05 & 0.205 & 0.023 & 0.135 & $\mathrm{~N}$ \\
\hline & & $8: 2$ & 1.92 & 0.36 & 0.183 & 0.046 & 0.135 & $\mathrm{~N}$ \\
\hline & & $7: 3$ & 2.04 & 0.53 & 0.160 & 0.070 & 0.135 & W \\
\hline & & $6: 4$ & 2.09 & 0.66 & 0.137 & 0.093 & 0.135 & W \\
\hline & & $5: 5$ & 2.11 & 0.76 & 0.114 & 0.016 & 0.136 & W \\
\hline & \multirow{5}{*}{0.01} & $9: 1$ & 0.8 & -0.38 & 0.305 & 0.034 & 0.034 & $\mathrm{~N}$ \\
\hline & & $8: 2$ & 1.05 & -0.08 & 0.271 & 0.068 & 0.034 & $\mathrm{~N}$ \\
\hline & & $7: 3$ & 1.17 & 0.1 & 0.237 & 0.102 & 0.034 & W \\
\hline & & $6: 4$ & 1.24 & 0.23 & 0.203 & 0.136 & 0.034 & W \\
\hline & & $5: 5$ & 1.26 & 0.33 & 0.169 & 0.170 & 0.034 & W \\
\hline & \multirow{5}{*}{0.005} & $9: 1$ & 0.3 & -0.63 & 0.334 & 0.037 & 0.017 & np \\
\hline & & $8: 2$ & 0.55 & -0.33 & 0.387 & 0.074 & 0.017 & np \\
\hline & & $7: 3$ & 0.68 & -0.15 & 0.260 & 0.115 & 0.018 & np \\
\hline & & $6: 4$ & 0.74 & -0.02 & 0.223 & 0.148 & 0.018 & np \\
\hline & & $5: 5$ & 0.76 & 0.08 & 0.185 & 0.186 & 0.018 & np \\
\hline \multirow{30}{*}{0.01} & \multirow{6}{*}{0.25} & $9: 1$ & 3.93 & 1.18 & 1.035 & 0.116 & 0.363 & $\mathrm{~N}$ \\
\hline & & $8: 2$ & 4.18 & 1.49 & 0.919 & 0.232 & 0.365 & $\mathrm{~N}$ \\
\hline & & $7: 3$ & 4.30 & 1.67 & 0.804 & 0.348 & 0.366 & $\mathrm{~N}$ \\
\hline & & $6: 4$ & 4.36 & 1.79 & 0.689 & 0.463 & 0.368 & $\mathrm{~N}+\mathrm{W}$ \\
\hline & & $5: 5$ & 4.39 & 1.89 & 0.574 & 0.579 & 0.369 & $\mathrm{~W}$ \\
\hline & & $4: 6$ & 4.37 & 1.97 & 0.459 & 0.694 & 0.371 & W \\
\hline & \multirow{6}{*}{0.1} & $9: 1$ & 3.66 & 1.05 & 1.554 & 0.173 & 0.179 & $\mathrm{~N}$ \\
\hline & & $8: 2$ & 3.92 & 1.35 & 1.380 & 0.345 & 0.180 & $\mathrm{~N}+\mathrm{W}$ \\
\hline & & $7: 3$ & 4.04 & 1.53 & 1.207 & 0.517 & 0.182 & $\mathrm{~W}+\mathrm{N}$ \\
\hline & & $6: 4$ & 4.11 & 1.66 & 1.033 & 0.671 & 0.183 & W \\
\hline & & $5: 5$ & 4.13 & 1.76 & 0.861 & 0.862 & 0.185 & W \\
\hline & & $4: 6$ & 4.12 & 1.84 & 0.688 & 1.032 & 0.186 & W \\
\hline & \multirow{6}{*}{0.05} & $9: 1$ & 3.31 & 0.87 & 1.954 & 0.215 & 0.096 & $\mathrm{~N}+\mathrm{W}$ \\
\hline & & $8: 2$ & 3.57 & 1.18 & 1.736 & 0.431 & 0.097 & W \\
\hline & & $7: 3$ & 3.70 & 1.36 & 1.513 & 0.655 & 0.098 & W \\
\hline & & $6: 4$ & 3.77 & 1.49 & 1.300 & 0.860 & 0.099 & W \\
\hline & & $5: 5$ & 3.80 & 1.59 & 1.082 & 1.074 & 0.101 & W \\
\hline & & $4: 6$ & 2.79 & 1.68 & 0.865 & 1.288 & 0.102 & W \\
\hline & \multirow{6}{*}{0.01} & $9: 1$ & 2.18 & 0.3 & 2.575 & 0.280 & 0.019 & $\mathrm{~W}$ \\
\hline & & $8: 2$ & 2.44 & 0.61 & 2.288 & 0.560 & 0.020 & $\mathrm{~W}$ \\
\hline & & $7: 3$ & 2.57 & 0.79 & 2.001 & 0.840 & 0.20 & W \\
\hline & & $6: 4$ & 2.65 & 0.93 & 1.715 & 1.120 & 0.21 & $\mathrm{~W}$ \\
\hline & & $5: 5$ & 2.68 & 1.03 & 1.429 & 1.400 & 0.021 & $\mathrm{~W}$ \\
\hline & & $4: 6$ & 2.66 & 1.12 & 1.143 & 1.680 & 0.022 & W \\
\hline & \multirow{6}{*}{0.005} & $9: 1$ & 1.61 & 0.02 & 2.694 & 0.293 & 0.010 & $\mathrm{np}$ \\
\hline & & $8: 2$ & 1.87 & 0.33 & 2.395 & 0.585 & 0.010 & np \\
\hline & & $7: 3$ & 2.00 & 0.51 & 2.095 & 0.877 & 0.010 & np \\
\hline & & $6: 4$ & 2.08 & 0.64 & 1.795 & 1.170 & 0.010 & $\stackrel{1}{W}$ \\
\hline & & $5: 5$ & 2.11 & 0.75 & 1.496 & 1.462 & 0.011 & $\mathrm{~W}$ \\
\hline & & $4: 6$ & 2.11 & 0.83 & 1.197 & 1.754 & 0.011 & W \\
\hline
\end{tabular}


Table 1. Cont.

\begin{tabular}{|c|c|c|c|c|c|c|c|c|}
\hline $\begin{array}{c}(\mathrm{Mg}, \mathrm{Ba}) \mathrm{Cl}_{2} \\
{[\mathrm{M}]}\end{array}$ & $\begin{array}{c}\mathrm{NaHCO}_{3} \\
{[\mathrm{M}]}\end{array}$ & $\mathrm{Mg} / \mathrm{Ba}$ & $S I_{\text {nrs }}$ & $S I_{\text {wit }}$ & $\begin{array}{l}\mathrm{aMg}^{2+} \\
{[\mathrm{mM}]}\end{array}$ & $\begin{array}{l}\mathrm{aBa}^{2+} \\
{[\mathrm{mM}]}\end{array}$ & $\begin{array}{c}\mathrm{aCO}_{3}^{2-} \\
{[\mathrm{mM}]}\end{array}$ & $\begin{array}{c}\text { Mineral } \\
\text { Phase }\end{array}$ \\
\hline \multirow{15}{*}{0.04} & \multirow{3}{*}{0.25} & $9: 1$ & 4.87 & 1.65 & 4.125 & 0.448 & 0.275 & $\mathrm{~N}$ \\
\hline & & $8: 2$ & 5.13 & 1.96 & 3.662 & 0.895 & 0.279 & $\mathrm{~N}+\mathrm{W}$ \\
\hline & & $7: 3$ & 5.26 & 2.14 & 3.200 & 1.341 & 0.282 & $\mathrm{~W}$ \\
\hline & \multirow{3}{*}{0.1} & $9: 1$ & 4.41 & 1.41 & 5.824 & 0.617 & 0.115 & $\mathrm{~N}$ \\
\hline & & $8: 2$ & 4.67 & 1.72 & 5.171 & 1.233 & 0.117 & $\mathrm{~W}+\mathrm{N}$ \\
\hline & & $7: 3$ & 4.8 & 1.90 & 4.518 & 1.847 & 0.119 & W \\
\hline & \multirow{3}{*}{0.05} & $9: 1$ & 3.93 & 1.17 & 6.843 & 0.715 & 0.057 & $\mathrm{~W}$ \\
\hline & & $8: 2$ & 4.20 & 1.48 & 6.077 & 1.430 & 0.058 & W \\
\hline & & $7: 3$ & 4.33 & 1.67 & 5.312 & 2.143 & 0.059 & W \\
\hline & \multirow{3}{*}{0.01} & $9: 1$ & 2.63 & 0.52 & 7.993 & 0.824 & 0.011 & W \\
\hline & & $8: 2$ & 2.90 & 0.83 & 7.104 & 1.648 & 0.013 & W \\
\hline & & $7: 3$ & 3.04 & 1.02 & 6.215 & 2.471 & 0.016 & W \\
\hline & \multirow{3}{*}{0.005} & $9: 1$ & 2.03 & 0.22 & 8.166 & 0.840 & 0.005 & $\mathrm{~W}$ \\
\hline & & $8: 2$ & 2.31 & 0.53 & 7.259 & 1.680 & 0.006 & W \\
\hline & & $7: 3$ & 2.45 & 0.72 & 6.351 & 2.520 & 0.006 & W \\
\hline \multirow{12}{*}{0.05} & \multirow{4}{*}{0.25} & $9: 1$ & 5.00 & 1.71 & 5.145 & 0.554 & 0.256 & $\mathrm{~N}$ \\
\hline & & $8: 2$ & 5.26 & 2.02 & 4.566 & 1.105 & 0.260 & $\mathrm{~N}+\mathrm{W}$ \\
\hline & & $7: 3$ & 5.39 & 2.2 & 3.989 & 1.656 & 0.263 & W \\
\hline & & $6: 4$ & 5.46 & 2.33 & 3.414 & 2.205 & 0.267 & W \\
\hline & \multirow{4}{*}{0.1} & $9: 1$ & 4.49 & 1.45 & 7.142 & 0.747 & 0.104 & $\mathrm{~W}+\mathrm{N}$ \\
\hline & & $8: 2$ & 4.76 & 1.76 & 6.340 & 1.493 & 0.107 & W \\
\hline & & $7: 3$ & 4.89 & 1.95 & 5.540 & 2.236 & 0.109 & W \\
\hline & & $6: 4$ & 4.97 & 2.08 & 4.742 & 2.978 & 0.111 & W \\
\hline & \multirow{4}{*}{0.05} & $9: 1$ & 4.00 & 1.2 & 8.277 & 0.854 & 0.051 & W \\
\hline & & $8: 2$ & 4.27 & 1.51 & 7.351 & 1.706 & 0.053 & W \\
\hline & & $7: 3$ & 4.41 & 1.7 & 6.427 & 2.558 & 0.054 & W \\
\hline & & $6: 4$ & 4.48 & 1.83 & 5.504 & 3.408 & 0.055 & W \\
\hline
\end{tabular}

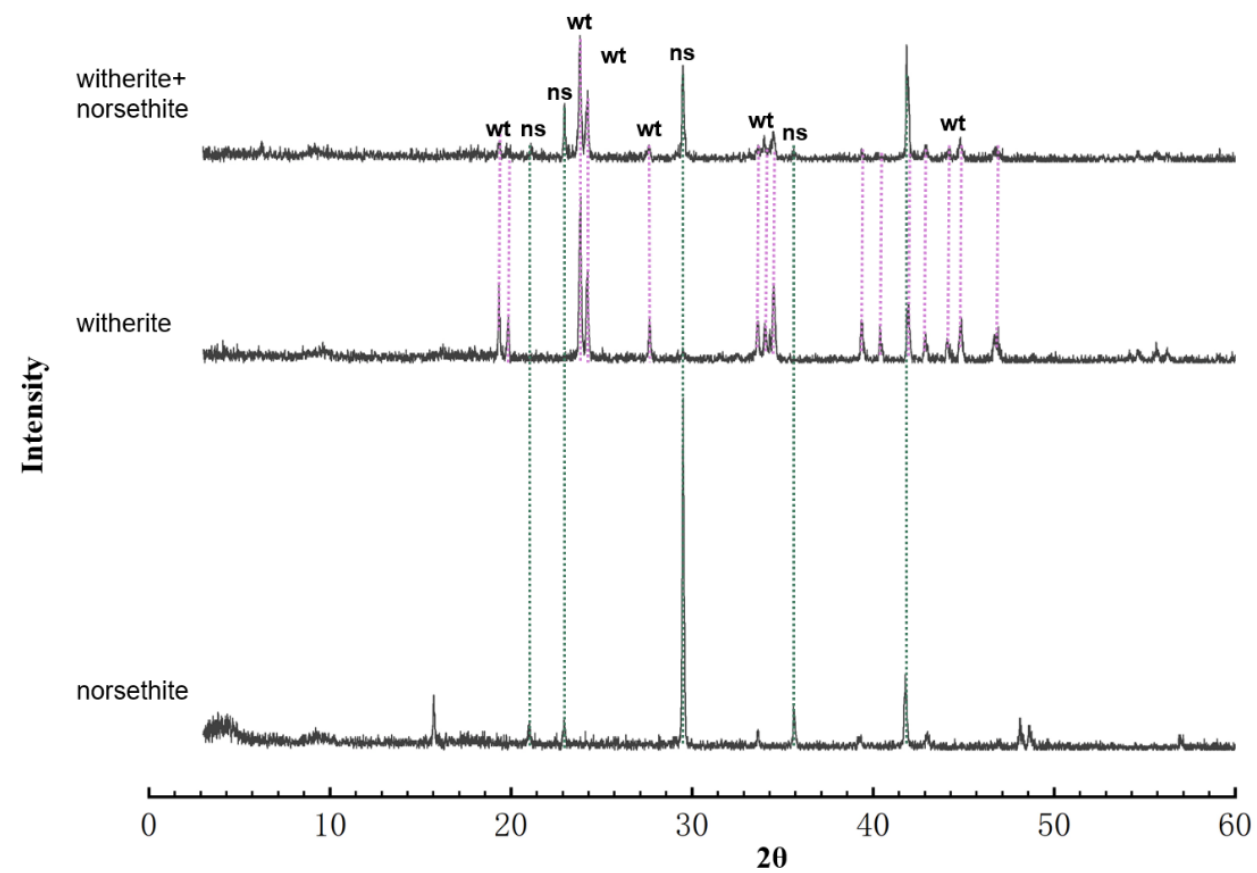

Figure 1. A sample XRD spectra of the precipitates in aqueous experiments in solutions containing $0.25 \mathrm{M} \mathrm{NaHCO}_{3}$ and $0.01 \mathrm{M}\left(\mathrm{Mg}, \mathrm{Ba}^{2} \mathrm{Cl}_{2}\right.$ (ns: norsethite; wt: witherite; bottom spectrum: $\mathrm{Mg} / \mathrm{Ba}=7 / 3$; bottom spectrum: $\mathrm{Mg} / \mathrm{Ba}=6 / 4$ (top); middle spectrum: $\mathrm{Mg} / \mathrm{Ba}=5 / 5$ ). 


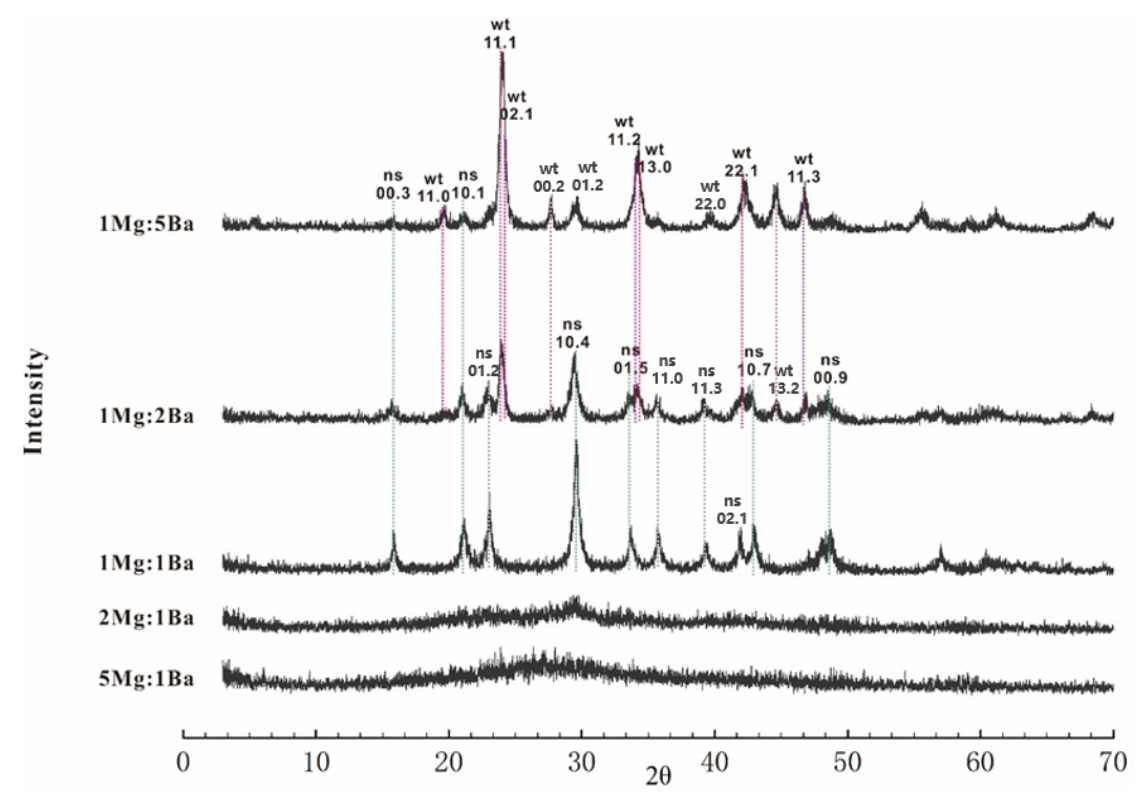

Figure 2. XRD spectra of the precipitates in the FMD experiments (ns: norsethite, wt: witherite). All visible peaks below $2 \theta$ of $55^{\circ}$ were able to be assigned to norsethite and witherite, suggesting that those two minerals may be the only phases that occurred in the experiments. Notice the lack of crystallinity at conditions of $2 \mathrm{Mg}: 1 \mathrm{Ba}$ and $5 \mathrm{Mg}: 1 \mathrm{Ba}$ as well as the presence of norsethite (10.1) and (00.3) peaks at $1 \mathrm{Mg}: 5 \mathrm{Ba}$.

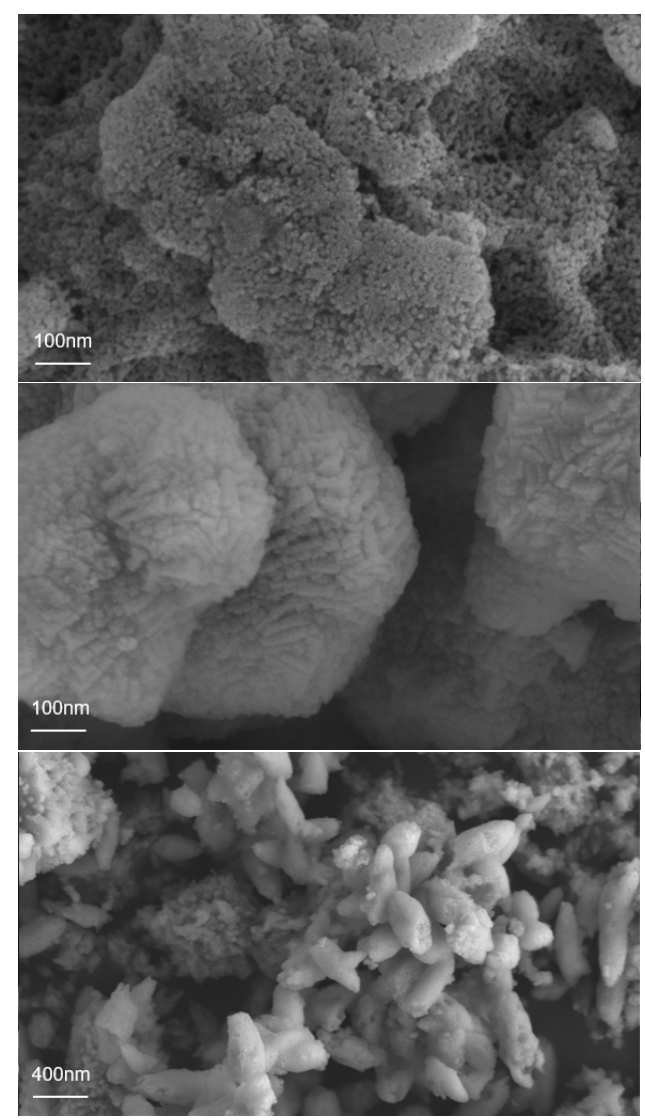

Figure 3. SEM photomicrographs of the precipitates in FMD experiments (upper: $\mathrm{Mg} / \mathrm{Ba}=5: 1$, amorphous aggregates; middle: $\mathrm{Mg} / \mathrm{Ba}=1: 1$, rhombohedral norsethite; lower: $\mathrm{Mg} / \mathrm{Ba}=1: 5$, lenticular witherite). 


\section{Discussion}

\subsection{Hydration Hindrance}

Two observations stand out distinctively from the aqueous experiments. (1) Incongruent crystallization $\left([\mathrm{Mg} / \mathrm{Ca}] \mathrm{s}_{\text {olid }} /[\mathrm{Mg} / \mathrm{Ca}]_{\text {solution }} \neq 1\right)$ occurred for exclusive norsethite formation as the solutions were required to have more $\mathrm{Mg}$ than $\mathrm{Ba}$ with an observed minimal value of $\mathrm{Mg} / \mathrm{Ba} \approx 7 / 3$, and (2) norsethite was never detected in solutions with $\mathrm{Mg} / \mathrm{Ba}<6 / 4$, whereas witherite could crystallize in $\mathrm{Mg}^{2+}$ dominated (as strong as $\mathrm{Mg}: \mathrm{Ba}=9: 1$ ) conditions (provided that the cation-to-anion ratio is high). The requirement of Mg-enriched solution to precipitate norsethite was observed previously by Lippmann [4] and Hood et al. [36] with a relative abundance of $\mathrm{Mg} / \mathrm{Ba} \approx 1.6$ while maintaining $\mathrm{CO}_{3}{ }^{2-}$ at a fixed concentration $(0.5 \mathrm{M})$. A plausible conclusion we can draw from these findings is that the stronger hydration of magnesium (than of $\mathrm{Ba}^{2+}$ ) may have limited $\mathrm{Mg}^{2+}$ from being in the free (dehydrated) state, so much so that $50 \%$ more $\mathrm{Mg}^{2+}$ was needed to match the quantity of free $\mathrm{Ba}^{2+}$ ions in the solutions. At the opposite end, although witherite appeared to form more easily in the $\mathrm{Mg}-\mathrm{Ba}-\mathrm{CO}_{2}-\mathrm{H}_{2} \mathrm{O}$ system given that the $\log \Omega_{\mathrm{W}}$ is smaller throughout the experiments by a factor of $2-10$ in comparison with $\log \Omega_{N}$, norsethite nevertheless crystallizes readily and can often be the exclusive precipitate at specific conditions $(\mathrm{Mg} / \mathrm{Ba}>\sim 7 / 3$, cation/anion $<\sim 60)$. Aqueous crystallization of norsethite at ambient conditions is known all along $[4,35,38,45,46]$ but is not known to require additional energy input other than supersaturation, and thus, it is inconsistent with the view that $\mathrm{Mg}^{2+}-\mathrm{H}_{2} \mathrm{O}$ interactions act as a barrier to preventing magnesium ions from entering the rhombohedral carbonate lattice.

Contrasting with the Mg-rich requirement for norsethite precipitation in aqueous environment, norsethite can crystallization in Mg-depleted FMD solutions with $\mathrm{Mg} / \mathrm{Ba}=1 / 2-1 / 5$. These observations on the one hand appear to be largely in line with the expectations of the $\mathrm{Mg}$ hydration theory, considering that the binding energy of $\mathrm{Mg}^{2+}$ with FMD $\left(\sim 125 \mathrm{kcal} / \mathrm{mol}\right.$ [47]) is significantly smaller than with $\mathrm{H}_{2} \mathrm{O}(\sim 260 \mathrm{kcal} / \mathrm{mol}[22,48])$, and the hydrogen bonds between formamide molecules $(8-13 \mathrm{~kJ} / \mathrm{mol}$ for $\mathrm{NH} \cdots \mathrm{O}$ and $\mathrm{NH} \cdots \mathrm{N})$ are meaningfully weaker than that between water molecules $(21 \mathrm{~kJ} / \mathrm{mol}$ for $\mathrm{OH} \cdots \mathrm{O})$ [49]. Simply put, it is reasonable to assume that, while the stronger (relative to $\mathrm{Ba}^{2+}$ ) hydration of $\mathrm{Mg}^{2+}$ dictates that magnesium ions stay largely in a hydrated form in aqueous solutions, the FMD solvation shell around $\mathrm{Mg}^{2+}$ is not as rigid and tight as the hydration shell, allowing for the presence of sufficient amount of free magnesium ion to participate in the crystallization reactions. On the other hand, the same rationale would lead one to expect the crystallization of anhydrous magnesium carbonate in FMD when this assumption is extended to $\mathrm{Mg}$ dominated conditions. However, experimental results, showing the lack of crystallinity in precipitates formed at conditions of $\mathrm{Mg} / \mathrm{Ba}>1$ (Figure 2), defied this logic reasoning. Furthermore, in comparison with the amorphous calcium carbonate (ACC) formed in the presence of $\mathrm{Mg}$ ions, the $\mathrm{Mg}-\mathrm{Ba}-\mathrm{CO}_{3}$ amorphous precipitate (Figure 3 upper) had a rather evenly distributed particle size instead of a mixture of distinctly sized populations [50], suggesting the occurrence of a monotonous short range order (the recurrence of $\mathrm{Ba}-\mathrm{O}$ and $\mathrm{Mg}-\mathrm{O}$ coordination) rather than the commonly observed $\mathrm{Ca}-\mathrm{ACC}$ (mainly $\mathrm{Ca}-\mathrm{O}$ order) and $\mathrm{Mg}-\mathrm{ACC}$ (both $\mathrm{Ca}-\mathrm{O}$ and $\mathrm{Mg}-\mathrm{O}$ order) in the $\mathrm{Mg}-\mathrm{Ca}-\mathrm{CO}_{3}$ system.

\subsection{Structural Restraints}

The lack of long-range orders in carbonate precipitates formed in Mg-rich FMD solutions was first observed in the $\mathrm{Ca}-\mathrm{Mg}-\mathrm{CO}_{2}$ system [51], where different from the $\mathrm{Ba}-\mathrm{Mg}-\mathrm{CO}_{2}$ system of concern in this study, congruent crystallization of $\mathrm{MgCa}\left(\mathrm{CO}_{3}\right)_{2}$ (dolomite) did not occur; high $\mathrm{Mg}(37 \%$ mole ratio) calcite instead formed at $\mathrm{Mg} / \mathrm{Ca}=1$. Given the absence of $\mathrm{H}_{2} \mathrm{O}$ in the experiments, the authors deduced that hydration may be an external force that is partially responsible for hindering dolomite and magnesite formation at ambient conditions, and crystal structural restraints, particularly reduced freedom of the $\mathrm{CO}_{3}$ groups and the increased lattice strains resulting from the size difference between 
$\mathrm{Mg}^{2+}$ and $\mathrm{Ca}^{2+}$ ions, may be the inherent factor preventing magnesium from entering the trigonal carbonate structure at ambient conditions. A later study [52] presented additional evidence embracing the premise that $\mathrm{Mg}$ for $\mathrm{Ca}$ substitution in calcite is limited to $<40 \%$. In the context of lacking dolomite formation in the $\mathrm{Ca}-\mathrm{Mg}-\mathrm{CO}_{2}-\mathrm{FMD}$ system, the unhindered crystallization of norsethite at $\mathrm{Mg} / \mathrm{Ba}=1$ observed in the present study appears to be consistent with the view of structural restraints. This is because, unlike dolomite $(R \overline{3})$, the $\mathrm{CO}_{3}$ groups in the norsethite (low temperature polymorph, $R \overline{3} \mathrm{c}$ ) are not as rigidly constrained. The refined norsethite structure by Effenberger et al. [33] indicates that the carbonate groups stacked along the $c$ direction do not strictly alternate their orientations in adjacent layers but instead rotate clockwise and anti-clockwise successively within a plane and in the $c$-axix (compare Figure 9a,c in Effenberger et al., 2014 [33]). In doing so, the unit cell doubles its size in the $c$-direction and the resultant structure allows for the large cation $\mathrm{Ba}^{2+}$ to increase its coordination number while maintaining the octahedral coordination of the smaller ion $\mathrm{Mg}^{2+}$ without creating much stress. In contrast, the dolomite structure does not have the luxury to relax because the $R \overline{3}$ symmetry dictates that the planar $\mathrm{CO}_{3}$ rotates $60^{\circ}$ in alternate layers. Thus, it appears that the lack of flexibility in the $a-b$ plane is a key parameter limiting dolomite crystallization at ambient conditions. In their study of $\mathrm{PbMg}\left(\mathrm{CO}_{3}\right)_{2}$ and norsethite crystallization, Pimentel and Pina [39] observed a reduction in the formation rate associated with the cation size decrease from $\mathrm{Ba}$ to $\mathrm{Pb}$ and proposed that the shape and relative size of the constituent coordination polyhedra may play a fundamental role (may be more relevant than magnesium hydration) in controlling the stability of dolomite-like structures such as those involving $\mathrm{Mg}^{2+}, \mathrm{Ca}^{2+}, \mathrm{Ba}^{2+}, \mathrm{Pb}^{2+}$, and $\mathrm{Sr}^{2+}$. Together, the findings to date suggest that structural flexibility in terms of adapting to the variable coordination of the non-Mg cations is critical for long range order development in all rhombohedral binary carbonate systems.

Considerations in structural restraints also lead us to speculate that magnesium carbonate formation may be an initial step in the reaction pathways of dolomite and norsethite crystallization. Two lines of thought are factored in this proposition. First, anhydrous carbonate can crystallize into two crystal systems: trigonal or orthorhombic. A general understanding [53-55] is that minerals with cations smaller than $\mathrm{Ca}^{2+}$ (ionic radius $\mathrm{r}=100 \mathrm{pm}$ ) adopt the trigonal structure (metal ions coordinated by six oxygens), whereas those larger than $\mathrm{Ca}^{2+}$ usually take on the orthorhombic form (metal ions coordinated by nine oxygens). Calcium, being the pivot, can be either trigonal (calcite) or orthorhombic (aragonite). As such, it is expected that magnesite $\mathrm{MgCO}_{3}$ and witherite $\mathrm{Ba}\left(\mathrm{CO}_{3}\right)_{2}$ are exclusively trigonal and orthorhombic, respectively, given the cation size of $\mathrm{Mg}^{2+}$ $(\mathrm{r}=72 \mathrm{pm})$ and $\mathrm{Ba}^{2+}(\mathrm{r}=152 \mathrm{pm})$. When binary systems are concerned, while it is conceivable that dolomite and proto-dolomite adopt a trigonal structure (because of the structural flexibility of calcium carbonate), the rationale for norsethite's structural preference is not so distinctly discernable due to the trigonal and orthorhombic combination of the end members. The fact that norsethite ends up in the trigonal system indicates that the rhombohedral structure in principle is the thermodynamically more stable one for a $\mathrm{Mg}-\mathrm{Ba}$ binary carbonate crystal. Moreover, the occurrence of norsethite and witherite co-precipitation signals that, while Ba can be incorporated in both trigonal and orthorhombic structures, magnesium on the other hand can only enter crystals with trigonal symmetry. Thus, on the basis that magnesium and barium do not form solid solution $(\mathrm{Ba}, \mathrm{Mg}) \mathrm{CO}_{3}$, we deduce that the initial step of norsethite crystallization is more likely the formation of magnesite units, which allow for a later or subsequent incorporation of Ba for the nucleation to continue. Conversely, if witherite is the first unit to form, the inability of $\mathrm{Mg}$ to enter the orthorhombic structure leads to a discontinuation of the crystallization process without the formation of norsethite in the end. Second, a common behavior of the $\mathrm{Ca}-\mathrm{Mg}-\mathrm{CO}_{2}$ and $\mathrm{Ba}-\mathrm{Mg}-\mathrm{CO}_{2}$ system in non-aqueous environment is the lack of crystalline precipitates in Mg-dominated solutions. This is surprising because $\sim 33 \%$ to $\sim 17 \%$ of solvated cations in those scenarios $(\mathrm{Mg} / \mathrm{Ba}$ and $\mathrm{Mg} / \mathrm{Ca}=2$ and 5, this study and $\mathrm{Xu}$ et al., 2013 [51]) are barium and calcium and should result in witherite and calcite crystallization, as they did 
in aqueous environments. A plausible interpretation is that $\mathrm{Mg}^{2+}$, which may be less stable in an un-hydrated form due to the high charge density relative to Ba and $\mathrm{Ca}$ ions, has the advantage to bind with $\mathrm{CO}_{3}{ }^{2-}$ first. When $\mathrm{Mg}$ is the minority ion in the solution and binds preferentially with carbonate ions, $\mathrm{Ba}^{2+}$ and $\mathrm{Ca}^{2+}$ can interact with the remaining $\mathrm{CO}_{3}{ }^{2-}$ to form witherite and calcite or can be incorporated in the prior-formed $\mathrm{Mg}-\mathrm{CO}_{3}$ unit to crystallize in norsethite and high-Mg calcite. In Mg-dominating solutions, however, rapid interactions of $\mathrm{Mg}$ with $\mathrm{CO}_{3}$ ions lead to amorphous magnesium carbonate precipitation (on the assumption that the $\mathrm{Mg}-\mathrm{CO}_{3}$ units cannot stack to form $3 \mathrm{D}$ crystalline structures due to the entropy penalty in the $\mathrm{CO}_{3}$ groups) [51] and a quick consumption of $\mathrm{CO}_{3}{ }^{2+}$, leaving $\mathrm{Ba}^{2+}$ and $\mathrm{Ca}^{2+}$ behind to stay in the solution without their host minerals witherite and calcite or to occur as minor components in the amorphous phases.

It is worth noting that a number of previous studies actually found $[4,38,40,45,56] \mathrm{BaCO}_{3}$, instead of $\mathrm{MgCO}_{3}$ being a precursor of norsethite at atmospheric conditions. Considering the recent finding that norsethite formation proceeds through a crystallization (chiefly of $\mathrm{Na}_{3} \mathrm{Mg}\left(\mathrm{CO}_{3}\right)_{2} \mathrm{Cl}$, with minor witherite and norsethite)-dissolution-recrystallization (of norethite) pathway [38], we suspect the incorporation of Ba into the trigonal carbonate structure (or the transformation of $\mathrm{BaCO}_{3}$ from orthorhombic to rhombohedral class) is a kinetically unfavored process. This may be especially true at low $\mathrm{T}$, where the formation of ordered $\mathrm{MgCO}_{3}$ is challenging and the orthorhombic template for $\mathrm{BaCO}_{3}$ to epitaxially grow on is lacking. As such, witherite is expected to form first but dissolves subsequently to release $\mathrm{Ba}^{2+}$ once $\mathrm{MgCO}_{3}$ units are in place to crystallize $\mathrm{MgBa}\left(\mathrm{CO}_{3}\right)_{2}$. At higher T when magnesite can readily form and the orthorhombic to rhombohedral transformation for $\mathrm{BaCO}_{3}$ is less hindered, one should expect $\mathrm{MgCO}_{3}$ to be a precursor of norsethite. This view is in fact consistent with the experimental observation that magnesite is the only precursor during norsethite crystallization at temperatures above $100{ }^{\circ} \mathrm{C}$ [57].

\subsection{Relative Effect of $\mathrm{Mg}$ Hydration and Structural Restraints}

The above discussion seems to converge on a conclusion that both Mg hydration and lattice structure are in play in limiting dolomite formation at ambient conditions. We now try to evaluate the relative importance of the two barriers. At a microscopic level, crystallization is characterized by the process of particle attachment and detachment. One effective approach to quantify this process is through the application of the transition state theory. Since dolomite (and magnesite in the same sense) is the thermodynamically stable phase at ambient conditions [18,58-61], the difficulty to crystallize such minerals is safely ascribed to the reaction kinetics. In the TST approach, the kinetic limitations can be assessed specifically by examining the concentration of the activated complex at constant temperature. To a first-degree approximation, we assume the nucleation of norsethite proceeds through the following reaction (Equation (1)):

$$
\mathrm{Mg}^{2+}+\mathrm{Ba}^{2+}+2 \mathrm{CO}_{3}{ }^{2-} \rightleftharpoons\left(\mathrm{MgCO}_{3} \cdot \mathrm{BaCO}_{3}\right)^{\ddagger} \rightarrow \mathrm{MgBa}\left(\mathrm{CO}_{3}\right)_{2}
$$

where $\left(\mathrm{BaCO}_{3} \cdot \mathrm{MgCO}_{3}\right)^{\ddagger}$ refers to the activated complex and $\mathrm{Mg}^{2+}, \mathrm{Ba}^{2+}$, and $\mathrm{CO}_{3}{ }^{2-}$ are the effective concentrations of the reactant ions. As the TST model is thermodynamics based, the following relations exist in the $\mathrm{Ba}-\mathrm{Mg}-\mathrm{CO}_{2}$ system (Equation (2)):

$$
\mathrm{K}_{\mathrm{N}}^{\ddagger}=\left[\left(\mathrm{MgCO}_{3} \cdot \mathrm{BaCO}_{3}\right)^{\ddagger}\right] /\left[\mathrm{Mg}^{2+}\right]\left[\mathrm{Ba}^{2+}\right]\left[\mathrm{CO}_{3}{ }^{2-}\right]^{2}=\exp \left(-\Delta \mathrm{G}^{\ddagger}{ }_{\mathrm{N}} / \mathrm{RT}\right)
$$

where $K^{\ddagger} \mathrm{N}$ and $\Delta \mathrm{G}^{\ddagger} \mathrm{N}$ are the equilibrium formation constants and the activation free energy (Gibbs energy of formation of the activated complex) for norsethite crystallization. It then follows that the concentration of the activated complex satisfies the following expression (Equation (3)):

$$
\left[\left(\mathrm{MgCO}_{3} \cdot \mathrm{BaCO}_{3}\right)^{\ddagger}\right]=\left[\mathrm{Mg}^{2+}\right]\left[\mathrm{Ba}^{2+}\right]\left[\mathrm{CO}_{3}{ }^{2-}\right]^{2}\left[\exp \left(-\Delta \mathrm{G}^{\ddagger} \mathrm{N} / \mathrm{RT}\right)\right]
$$


Note that the maximal concentration for the activated complex implicated by Equation (3) can only be achieved at the conditions of $\left[\mathrm{Mg}^{2+}\right] /\left[\mathrm{Ba}^{2+}\right]=1$. This is because the charge neutrality requirement for chemical reactions stipulates the total cation concentration $\left(\left[\mathrm{Mg}^{2+}\right]+\left[\mathrm{Ba}^{2+}\right]\right)$ in the system to be a fixed value, and consequently, the ionic activity product of the cations reaches the maximum at equal relative abundance for each individual cations. As the minimal relative abundance of $\mathrm{Mg}$ for norsethite to form in FMD is $\mathrm{Mg} / \mathrm{Ba}=1 / 5$, the increased value of $\mathrm{Mg} / \mathrm{Ba}=6 / 4$ in water suggests that hydration may have reduced the availability of free $\mathrm{Mg}$ ions (or the reactivity of $\mathrm{Mg}^{2+}$ ) by $\sim 88 \%$.

Applying the TST theory to the $\mathrm{Ca}-\mathrm{Mg}-\mathrm{CO}_{2}$ system, we may have the following relations (Equations (4)-(6)):

$$
\begin{gathered}
\mathrm{Mg}^{2+}+\mathrm{Ca}^{2+}+2 \mathrm{CO}_{3}{ }^{2-} \rightleftharpoons\left(\mathrm{MgCO}_{3} \cdot \mathrm{CaCO}_{3}\right)^{\ddagger} \rightarrow \mathrm{MgCa}\left(\mathrm{CO}_{3}\right)_{2} \\
\left.K^{\ddagger} \mathrm{D}=\left[\left(\mathrm{MgCO}_{3} \cdot \mathrm{CaCO}_{3}\right)^{\ddagger}\right] /\left[\mathrm{Mg}^{2+}\right] \mathrm{Ca}^{2+}\right]\left[\mathrm{CO}_{3}{ }^{2-}\right]^{2}=\exp \left(-\Delta \mathrm{G}^{\ddagger} \mathrm{D} / \mathrm{RT}\right) \\
{\left[\left(\mathrm{MgCO}_{3} \cdot \mathrm{CaCO}_{3}\right)^{\ddagger}\right]=\left[\mathrm{Mg}^{2+}\right]\left[\mathrm{Ca}^{2+}\right]\left[\mathrm{CO}_{3}{ }^{2-}\right]^{2}\left[\exp \left(-\Delta \mathrm{G}^{\ddagger} \mathrm{D} / \mathrm{RT}\right)\right]}
\end{gathered}
$$

The similarity of these equations to Equations (1)-(3) suggests that the weakened solvation effect on $\mathrm{Mg}$ in FMD should also lead to the formation of dolomite (at least proto-dolomite) in the non-aqueous solution with $\mathrm{Mg} / \mathrm{Ca}=1$ if the magnitude of $\left[\exp \left(-\Delta \mathrm{G}^{\ddagger} \mathrm{D} / \mathrm{RT}\right)\right]$ is comparable with that for norsethtie crystallization. Published $\Delta \mathrm{G}^{\ddagger}$ values for the two binary phases do not support this prediction as $\Delta \mathrm{G}^{\ddagger} \mathrm{D}$ is greater than $\Delta \mathrm{G}^{\ddagger} \mathrm{N}$ by more than $50 \%$. Since the solvation effect of FMD on Mg should be the same in both systems, the higher $\Delta \mathrm{G}^{\ddagger} \mathrm{D}$ in conjunction with the lack of any carbonate phases with $\mathrm{Mg}: \mathrm{Ca} \approx 1$ in the $\mathrm{Mg}-\mathrm{Ca}-\mathrm{CO}_{2}$ non-aqueous solutions indicates that, besides $\mathrm{Mg}$ hydration, additional hindrance inherent to the Gibbs free energy of the activated complex exists in restricting the formation of dolomite and proto-dolomite at ambient conditions.

The free energy term $\exp \left(-\Delta \mathrm{G}^{\ddagger} / \mathrm{RT}\right)$ can be further break down to [exp $\left(-\Delta \mathrm{H}^{\ddagger} / \mathrm{RT}\right) \exp$ $\left.\left(\Delta \mathrm{S}^{\ddagger} / \mathrm{T}\right)\right]$ based upon the fundamental relation of $\mathrm{G}=\mathrm{H}-\mathrm{TS}$. Here, the enthalpic component is a reflection of bond strength, and the entropy term is the spatial configuration of the activated complex. The published data (Table 2) $[40,62-66]$ reveal that $\left(\mathrm{MgCO}_{3} \cdot \mathrm{CaCO}_{3}\right)^{\ddagger}$ is in fact an entropically more favored species than $\left(\mathrm{MgCO}_{3} \cdot \mathrm{BaCO}_{3}\right)^{\ddagger}$ is, stating that the high $\Delta \mathrm{G}^{\ddagger} \mathrm{D}$ is derived primarily from the enthalpic contribution, i.e., weaker bonding in the activated complex. The $\mathrm{Ca}-\mathrm{O}$ bond is only $~ 17 \%$ weaker than the $\mathrm{Ba}-\mathrm{O}$ bond (dissociation energy $464 \mathrm{~kJ} / \mathrm{mol}$ and $563 \mathrm{~kJ} / \mathrm{mol}$, respectively), indicating the $\Delta \mathrm{H}^{\ddagger}$ for $\left(\mathrm{MgCO}_{3} \cdot \mathrm{CaCO}_{3}\right)^{\ddagger}$ and $\left(\mathrm{MgCO}_{3} \cdot \mathrm{BaCO}_{3}\right)^{\ddagger}$ should only differ slightly as long as the spatial arrangement of atoms (i.e., bond angle and distance) in the two species are similar. The fact that $\Delta \mathrm{H}^{\ddagger} \mathrm{D}$ $(132 \mathrm{~kJ} / \mathrm{mol})$ is more than $\sim 80 \%$ higher than $\Delta \mathrm{H}^{\ddagger}{ }_{\mathrm{N}}(77.52 \mathrm{~kJ} / \mathrm{mol})$ suggests the existence of a significant structural difference between the two activation states, consistent with the entropic factor of the two species $\left(\Delta \mathrm{S}^{\ddagger} \mathrm{N}=-18.1 \mathrm{~J} / \mathrm{K} / \mathrm{mol}\right.$ and $\left.\Delta \mathrm{S}^{\ddagger} \mathrm{D}=29.7 \mathrm{~J} / \mathrm{K} / \mathrm{mol}\right)$. A potential explanation is that $\left(\mathrm{MgCO}_{3} \cdot \mathrm{BaCO}_{3}\right)^{\ddagger}$ may have a more ordered structure due to the inability of $\mathrm{Mg}^{2+}$ and $\mathrm{Ba}^{2+}$ to form a single mixed layer, so that the oxygens in the $\mathrm{CO}_{3}$ groups can bind to $\mathrm{Mg}$ in the $+c$ direction and $\mathrm{Ba}$ in the $-c$ direction without distorting the bond lengths on either side. On the contrary, $\left(\mathrm{CaCO}_{3} \cdot \mathrm{MgCO}_{3}\right)^{\ddagger}$ may be more disordered because $\mathrm{Ca}$ and $\mathrm{Mg}$ can replace each other in any binding geometry, resulting in oxygen-metal bonds in any orientation of the $\mathrm{CO}_{3}$ groups having both $\mathrm{Ca}$ and $\mathrm{Mg}$ attached. Consequently, the bonds cannot adopt the optimal length and angle due to the size difference of $\mathrm{Ca}$ and $\mathrm{Mg}$ ions (bond length $\mathrm{Mg}-\mathrm{O} 2.082 \AA, \mathrm{Ca}-\mathrm{O} 2.382 \AA$ in dolomite). After all, activated complexes differ from but resemble the products one way or the other. It is therefore reasonable to speculate that the ordered structure of norsethite and the common occurrence of disordered $(\mathrm{Ca}, \mathrm{Mg}) \mathrm{CO}_{3}$ phases may be a reflection of the corresponding activated complex one way or the other. 
Table 2. Thermodynamic properties of the activated complexes for different carbonate minerals $[24,40,62,63,66]$.

\begin{tabular}{|c|c|c|c|c|}
\hline Mineral & $\mathrm{T}(\mathrm{K})$ & $\Delta \mathrm{H}^{\neq}\left(\mathrm{kJmol}^{-1}\right)$ & $\Delta S^{\neq}\left(\mathrm{JK}^{-1} \mathrm{~mol}^{-1}\right)$ & $\Delta \mathrm{G}^{\neq}\left(\mathrm{kJmol}^{-1}\right)$ \\
\hline calcite & 298 & 44.2 & -120.3 & 81.3 \\
\hline norsethite & 298 & 77.5 & -18.1 & 82.9 \\
\hline dolomite & 298 & 132.0 & 29.7 & 125.4 \\
\hline
\end{tabular}

Finally, the estimated $\sim 88 \%$ reduction in $\left[\mathrm{Mg}^{2+}\right]$ due to hydration leads to a reaction quotient eight times smaller than the equilibrium formation constant $\left(\mathrm{K}_{\mathrm{N}}^{\ddagger}\right)$ for the activated complex (Equation (2)), equivalent to a $\sim 5 \mathrm{~kJ} / \mathrm{mol}$ energy deficiency to reach the required $\Delta \mathrm{G}^{\ddagger} \mathrm{N}$. The magnitude of fluctuation in the reported $\Delta \mathrm{G}^{\ddagger} \mathrm{N}(\sim 79-84 \mathrm{~kJ} / \mathrm{mol}$, Table 3) in solutions with various levels of the $\mathrm{Mg}$ :Ba ratio seems to agree with such a small effect of $\mathrm{Mg}$ hydration. While this energy penalty can be compensated by raising the relative abundance of $\mathrm{Mg}$ in solutions for norsethite formation, the same cannot be said for dolomite. Assuming that dolomite crystallizes in aqueous solutions if the $\Delta \mathrm{G}^{\ddagger}$ of the reaction $(\sim 125 \mathrm{~kJ} / \mathrm{mol})$ is lowered to a value close to that for norsethite $(\sim 80 \mathrm{~kJ} / \mathrm{mol}$, which incidentally is nearly identically to that for calcite, Table 2), on the basis that the $\sim 45 \mathrm{~kJ} / \mathrm{mol}$ difference between $\Delta \mathrm{G}^{\ddagger} \mathrm{D}$ and $\Delta \mathrm{G}^{\ddagger} \mathrm{N}$ (Table 2) results from a combination of $\mathrm{Mg}$ hydration and structural constraints, our data suggest that the former accounts for $\sim 12 \%$ while the latter accounts for $\sim 88 \%$ of the dolomite mineralization barrier.

Table 3. Thermodynamic properties of the activated complexes for norsethite formation in solutions with different values of the Mg-to-Ba ratio [40].

\begin{tabular}{|c|c|c|c|c|}
\hline Mg/Ba (Approximate Number) & $\mathrm{T}(\mathrm{K})$ & $\Delta \mathrm{H}^{\neq}\left(\mathrm{kJmol}^{-1}\right)$ & $\Delta S \neq\left(\mathrm{JK}^{-1} \mathrm{~mol}^{-1}\right)$ & $\Delta \mathrm{G}^{\neq}\left(\mathrm{kJmol}^{-1}\right)$ \\
\hline 10 & 298 & 95.8 & 39.0 & 84.1 \\
\hline 20 & 298 & 77.6 & -9.0 & 80.3 \\
\hline 40 & 298 & 70.1 & -29.6 & 78.9 \\
\hline
\end{tabular}

\section{Summary}

The $\mathrm{Mg}-\mathrm{Ba}-\mathrm{CO}_{2}$ system was investigated through crystallization experiments at various conditions in water and a non-aqueous environment to determine the minimal $\mathrm{Mg} / \mathrm{Ba}$ values at which norsethite can crystallize, and the measured difference was used to estimate the hydration effect on $\mathrm{Mg}^{2+}$ reactivity in the crystallization reactions. The experimental data suggest that hydration may have suppressed the reactivity of $\mathrm{Mg}^{2+}$ by close to $88 \%$ relative to that in FMD. Application of the TST model to the norsethite system revealed that the hydration effect on $\mathrm{Mg}$ has resulted in a reaction quotient that is approximately eight-fold smaller than the equilibrium formation constant for the activated complex, equivalent to $\sim 5 \mathrm{~kJ} / \mathrm{mol}$ energy penalty. In comparison to dolomite, the TST parameters indicate that the activated complex for norsethite crystallization appears to be entropically unfavored but has a significantly stronger bonding strength, leading to the activation free energy $\sim 50 \%$ lower than for dolomite crystallization. The $\sim 5 \mathrm{~kJ} / \mathrm{mol}$ energy penalty originating from $\mathrm{Mg}^{2+}$ hydration is approximately equivalent to $\sim 12 \%$ of the difference between $\Delta \mathrm{G}^{\ddagger} \mathrm{D}$ and $\Delta \mathrm{G}^{\ddagger} \mathrm{N}$, suggesting the hindrance for ambient condition dolomite mineralization may be derived primarily from the weaker bonding state in the transition state.

It is important to note that the simple approach adopted in this study may not be completely appropriate and can lead to erroneous conclusions. An important assumption made here is that the reaction pathway, the activated complex in specific, is similar for dolomite and norsethite crystallization reactions. Although less likely, it is still possible that the transition states of the reactions in Equations (1) and (4) differ to a certain degree. In addition, the assumption that $\Delta \mathrm{G}^{\ddagger} \mathrm{D}$ needs to be lowered to a level close to $\Delta \mathrm{G}^{\ddagger} \mathrm{N}$ in order for dolomite to crystallize may also be overly simplistic. For example, laboratory synthesis of dolomite is often possible at conditions near or above $100{ }^{\circ} \mathrm{C}$ [67]. At this temperature, $\Delta \mathrm{G}^{\ddagger} \mathrm{D}$ is in fact approximately $5 \mathrm{~kJ} / \mathrm{mol}$ lower than that at $298 \mathrm{~K}$ (Table 2) 
and can be fully accounted for by the Mg hydration effect. Despite the uncertainties, the results from the approach appear to be able to rationalize the fact that crystallization of the ordered binary carbonate $\mathrm{MgBa}\left(\mathrm{CO}_{3}\right)_{2}$ can proceed at the relative $\mathrm{Mg}$ abundance of $\mathrm{Mg}: \mathrm{Ba}=6: 4$ in ambient aqueous solutions, while at the similar conditions, not even disordered $(\mathrm{MgBa}) \mathrm{CO}_{3}$ with $\mathrm{Mg}$ content greater than 10\% [68-74] can readily form.

Author Contributions: H.T. conceptualized this study and drafted the manuscript. S.Z. and Y.W. carried out the crystallization experiments and material characterization and helped to finalize the manuscript. All authors have read and agreed to the published version of the manuscript.

Funding: This research was funded by the National Natural Science Foundation of China, grand No. NNSFC-41972041.

Data Availability Statement: The data presented in this study are available in the article.

Acknowledgments: We thank two anonymous reviewers and the academic editor Carlos Pina for their constructive suggestions and comments that have greatly improved this manuscript.

Conflicts of Interest: The authors declare no conflict of interest.

\section{References}

1. Sorby, H.C. XII.-On the cause of the production of different secondary forms of crystals. Mineral. Mag. J. Mineral. Soc. 1879, 3, 111-113. [CrossRef]

2. Bragg, W. The analysis of crystals by the X-ray spectrometer. Proc. R. Soc. Lond. 1914, 89, 468-489.

3. Wyckoff, R.W.G. The crystal structures of some carbonates of the calcite group. Am. J. Sci. 1920, 4, 317-360. [CrossRef]

4. Lippmann, F. Crystal chemistry of sedimentary carbonate minerals. In Sedimentary Carbonate Minerals; Springer: Berlin/Heidelberg Germany, 1973; pp. 5-96.

5. Reeder, R.J.; Barber, D.J. Carbonates: Mineralogy and chemistry; Mineralogical Society of America: Washington, DC, USA, 1983; Volume 11.

6. Plummer, L.; Wigley, T.; Parkhurst, D. The kinetics of calcite dissolution in $\mathrm{CO}_{2}$-water systems at $5^{\circ}$ to $60^{\circ} \mathrm{C}$ and 0.0 to 1.0 atm $\mathrm{CO}_{2}$. Am. J. Sci. 1978, 278, 179-216. [CrossRef]

7. Busenberg, E.; Plummer, L.; Mumpton, F. A comparative study of the dissolution and crystal growth kinetics of calcite and aragonite. Stud. Diagenesis USGS Bull. 1986, 1578, 139-168.

8. Teng, H.H.; Dove, P.M.; Orme, C.A.; De Yoreo, J. Thermodynamics of calcite growth: Baseline for understanding biomineral formation. Science 1998, 282, 724-727. [CrossRef] [PubMed]

9. Morse, J.W.; Arvidson, R.S.; Lüttge, A. Calcium carbonate formation and dissolution. Chem. Rev. 2007, 107, 342-381. [CrossRef]

10. Urosevic, M.; Rodriguez-Navarro, C.; Putnis, C.V.; Cardell, C.; Putnis, A.; Ruiz-Agudo, E. In situ nanoscale observations of the dissolution of $\{1014\}$ dolomite cleavage surfaces. Geochim. Cosmochim. Acta 2012, 80, 1-13. [CrossRef]

11. Chang, B.; Li, C.; Liu, D.; Foster, I.; Tripati, A.; Lloyd, M.K.; Maradiaga, I.; Luo, G.; An, Z.; She, Z. Massive formation of early diagenetic dolomite in the Ediacaran ocean: Constraints on the "dolomite problem". Proc. Natl. Acad. Sci. USA 2020, 117, 14005-14014. [CrossRef] [PubMed]

12. Cusack, M.; Freer, A. Biomineralization: Elemental and organic influence in carbonate systems. Chem. Rev. 2008, 108, 4433-4454. [CrossRef] [PubMed]

13. Raymo, M.E.; Ruddiman, W.F. Tectonic forcing of late Cenozoic climate. Nature 1992, 359, 117-122. [CrossRef]

14. Royer, D.L.; Berner, R.A.; Park, J. Climate sensitivity constrained by $\mathrm{CO}_{2}$ concentrations over the past 420 million years. Nature 2007, 446, 530-532. [CrossRef] [PubMed]

15. Bock, C.W.; Kaufman, A.; Glusker, J.P. Coordination of water to magnesium cations. Inorg. Chem. 1994, 33, 419-427. [CrossRef]

16. Zengler, D.; Dunham, J.; Ethington, R.L. Concepts and Models of Dolomitization; SEPM Society for Sedimentary Geology: Tulsa, OK, USA, 1980.

17. Christ, C.; Hostetler, P. Studies in the system $\mathrm{MgO}-\mathrm{SiO}_{2}-\mathrm{CO}_{2}-\mathrm{H}_{2} \mathrm{O}$ (II); the activity-product constant of magnesite. Am. J. Sci. 1970, 268, 439-453. [CrossRef]

18. Sayles, F.; Fyfe, W. The crystallization of magnesite from aqueous solution. Geochim. Cosmochim. Acta 1973, 37, 87-99. [CrossRef]

19. Deelman, J. Low-temperature synthesis of eitelite, $\mathrm{Na}_{2} \mathrm{CO}_{3} \cdot \mathrm{MgCO}_{3}$. Neues Jahrbuch für Mineralogie. Monatshefte 1984, 10, $468-480$.

20. Deelman, J. Breaking Ostwald's rule. Chem. Erde-Geochem. 2001, 61, 224-235.

21. Shannon, R.D. Revised effective ionic radii and systematic studies of interatomic distances in halides and chalcogenides. Acta Crystallogr. Sect. A: Cryst. Phys. Diffr. Theor. Gen. Crystallogr. 1976, 32, 751-767. [CrossRef]

22. Pavlov, M.; Siegbahn, P.E.; Sandström, M. Hydration of beryllium, magnesium, calcium, and zinc ions using density functional theory. J. Phys. Chem. A 1998, 102, 219-228. [CrossRef] 
23. Markham, G.D.; Glusker, J.P.; Bock, C.W. The arrangement of first-and second-sphere water molecules in divalent magnesium complexes: Results from molecular orbital and density functional theory and from structural crystallography. J. Phys. Chem. B 2002, 106, 5118-5134. [CrossRef]

24. Andersson, M.P.; Stipp, S.L. Predicting hydration energies for multivalent ions. J. Comput. Chem. 2014, 35, 2070-2075. [CrossRef] [PubMed]

25. Ikeda, T.; Boero, M.; Terakura, K. Hydration properties of magnesium and calcium ions from constrained first principles molecular dynamics. J. Chem. Phys. 2007, 127, 074503. [CrossRef] [PubMed]

26. Katz, A.K.; Glusker, J.P.; Beebe, S.A.; Bock, C.W. Calcium ion coordination: A comparison with that of beryllium, magnesium, and zinc. J. Am. Chem. Soc. 1996, 118, 5752-5763. [CrossRef]

27. Bruni, F.; Imberti, S.; Mancinelli, R.; Ricci, M. Aqueous solutions of divalent chlorides: Ions hydration shell and water structure. J. Chem. Phys. 2012, 136, 064520. [CrossRef]

28. Di Tommaso, D.; de Leeuw, N.H. First principles simulations of the structural and dynamical properties of hydrated metal ions $\mathrm{Me}^{2+}$ and solvated metal carbonates (Me=Ca, Mg, and Sr). Cryst. Growth Des. 2010, 10, 4292-4302. [CrossRef]

29. Ingham, B.; Ko, M.; Laycock, N.; Kirby, N.M.; Williams, D.E. First stages of siderite crystallisation during $\mathrm{CO}_{2}$ corrosion of steel evaluated using in situ synchrotron small-and wide-angle X-ray scattering. Faraday Discuss. 2015, 180, 171-190. [CrossRef]

30. Neuberg, C.; Rewald, B. Ueber kolloide und gelatinöse Verbindungen der Erdalkalien. Z. Für Chem. Und Ind. Der Kolloide 1908, 2, 354-357. [CrossRef]

31. Forsgren, J.; Frykstrand, S.; Grandfield, K.; Mihranyan, A.; Strømme, M. A template-free, ultra-adsorbing, high surface area carbonate nanostructure. PLoS ONE 2013, 8, e68486. [CrossRef]

32. Ende, M.; Effenberger, H.; Miletich, R. Evolution of the $\alpha$-BaMg$\left(\mathrm{CO}_{3}\right)_{2}$ low-temperature superstructure and the tricritical nature of its $\alpha-\beta$ phase transition. Acta Crystallogr. Sect. B Struct. Sci. Cryst. Eng. Mater. 2017, 73, 827-835. [CrossRef]

33. Effenberger, H.; Pippinger, T.; Libowitzky, E.; Lengauer, C.; Miletich, R. Synthetic norsethite, BaMg $\left(\mathrm{CO}_{3}\right)_{2}: \mathrm{Revised}_{\mathrm{c}} \mathrm{crystal}$ structure, thermal behaviour and displacive phase transition. Mineral. Mag. 2014, 78, 1589-1611. [CrossRef]

34. Lippmann, F. Die Kristallstruktur des Norsethit, $\mathrm{BaMg}\left(\mathrm{CO}_{3}\right)_{2}$, im Vergleich zum Dolomit, $\mathrm{CaMg}\left(\mathrm{CO}_{3}\right)_{2}$. Naturwissenschaften 1967, 54, 514. [CrossRef]

35. Lippmann, F. Syntheses of BaMg $\left(\mathrm{CO}_{3}\right)_{2}$ (Norsethite) at $20^{\circ} \mathrm{C}$ and the Formation of Dolomite in Sediments. In Recent Developments in Carbonate Sedimentology in Central Europe; Springer: Berlin/Heidelberg, Germany, 1968; pp. 33-37.

36. Hood, W.C.; Steidl, P.F.; Tschopp, D.G. Precipitation of norsethite at room temperature. Am. Mineral. J. Earth Planet. Mater. 1974, $59,471-474$.

37. Bötcher, M.E. Stable isotope fractionation during experimental formation of norsethite $\left(\mathrm{BaMg}\left[\mathrm{CO}_{3}\right]_{2}\right): \mathrm{A}$ mineral analogue of dolomite. Aquat. Geochem. 2000, 6, 201-212. [CrossRef]

38. Pimentel, C.; Pina, C.M. The formation of the dolomite-analogue norsethite: Reaction pathway and cation ordering. Geochim. Cosmochim. Acta 2014, 142, 217-223. [CrossRef]

39. Pimentel, C.; Pina, C.M. Reaction pathways towards the formation of dolomite-analogues at ambient conditions. Geochim. Cosmochim. Acta 2016, 178, 259-267. [CrossRef]

40. Lindner, M.; Saldi, G.D.; Carrocci, S.; Bénézeth, P.; Schott, J.; Jordan, G. On the growth of anhydrous Mg-bearing carbonatesImplications from norsethite growth kinetics. Geochim. Cosmochim. Acta 2018, 238, 424-437. [CrossRef]

41. Liu, C.; Li, W. Transformation of amorphous precursor to crystalline carbonate: Insights from Mg isotopes in the dolomiteanalogue mineral norsethite [BaMg $\left(\mathrm{CO}_{3}\right)_{2}$ ]. Geochim. Cosmochim. Acta 2020, 272, 1-20. [CrossRef]

42. Zhang, Y.-F.; Yao, Q.-Z.; Qian, F.-J.; Li, H.; Zhou, G.-T.; Fu, S.-Q. Formation pathway of norsethite dominated by solution chemistry under ambient conditions. Am. Mineral. J. Earth Planet. Mater. 2021, 106, 1306-1318. [CrossRef]

43. Rock, P.A.; Mandell, G.K.; Casey, W.H.; Walling, E.M. Gibbs energy of formation of dolomite from electrochemical cell measurements and theoretical calculations. Am. J. Sci. 2001, 301, 103-111. [CrossRef]

44. Bada, J.L.; Chalmers, J.H.; Cleaves, H.J. Is formamide a geochemically plausible prebiotic solvent? Phys. Chem. Chem. Phys. 2016, 18, 20085. [CrossRef] [PubMed]

45. Morrow, D.; Ricketts, B. Chemical controls on the precipitation of mineral analogues of dolomite: The sulfate enigma. Geology 1986, 14, 408-410. [CrossRef]

46. Longo, J.M.; Voight, K.C. Synthesis of mixed-metal carbonates by grinding. Solid State Ion. 1989, 32, 409-412. [CrossRef]

47. Mercero, J.M.; Fowler, J.E.; Ugalde, J.M. Aluminum (III) interactions with the acid derivative amino acid chains. J. Phys. Chem. A 2000, 104, 7053-7060. [CrossRef]

48. Peschke, M.; Blades, A.T.; Kebarle, P. Hydration energies and entropies for $\mathrm{Mg}^{2+}, \mathrm{Ca}^{2+}, \mathrm{Sr}^{2+}$, and $\mathrm{Ba}^{2+}$ from gas-phase ion-water molecule equilibria determinations. J. Phys. Chem. A 1998, 102, 9978-9985. [CrossRef]

49. Grushka, E.; Grinberg, N. Advances in Chromatography; CRC Press: Boca Raton, FL, USA, 2006; Volume 45.

50. Mergelsberg, S.T.; Yoreo, J.; Miller, Q.; Michel, F.M.; Dove, P.M. Metastable solubility and local structure of amorphous calcium carbonate (ACC). Geochim. Cosmochim. Acta 2020, 289. [CrossRef]

51. Xu, J.; Yan, C.; Zhang, F.F.; Konishi, H.; Xu, H.F.; Teng, H.H. Testing the cation-hydration effect on the crystallization of Ca-Mg-CO 3 systems. Proc. Natl. Acad. Sci. USA 2013, 110, 17750-17755. [CrossRef] [PubMed]

52. Hong, M.; Xu, J.; Teng, H.H. Evolution of calcite growth morphology in the presence of magnesium: Implications for the dolomite problem. Geochim. Cosmochim. Acta 2016, 172, 55-64. [CrossRef] 
53. Speer, J.A. Crystal chemistry and phase relations of orthorhombic carbonates. Rev. Mineral. Geochem. 1983, 11, 145-190.

54. Reeder, R.J. Crystal chemistry of the rhombohedral carbonates. Rev. Mineral. Geochem. 1983, 11, 1-47.

55. Speer, J.A. Crystal chemistry and phase relations of orthorhombic carbonates. In Carbonates; De Gruyter: Berlin, Germany, 2018; pp. 145-190.

56. Lindner, M.; Jordan, G. On the growth of witherite and its replacement by the Mg-bearing double carbonate norsethite: Implications for the dolomite problem. Am. Mineral. 2018, 103, 252-259. [CrossRef]

57. Lindner, M.; Saldi, G.D.; Jordan, G.; Schott, J. On the effect of aqueous barium on magnesite growth-A new route for the precipitation of the ordered anhydrous Mg-bearing double carbonate norsethite. Chem. Geol. 2017, 460, 93-105. [CrossRef]

58. Graf, D.L.; Goldsmith, J.R. Some hydrothermal syntheses of dolomite and protodolomite. J. Geol. 1956, 64, 173-186. [CrossRef]

59. Tribble, J.S.; Arvidson, R.S.; Lane III, M.; Mackenzie, F.T. Crystal chemistry, and thermodynamic and kinetic properties of calcite, dolomite, apatite, and biogenic silica: Applications to petrologic problems. Sediment. Geol. 1995, 95, 11-37. [CrossRef]

60. Land, L.S. The Isotopic and Trace Element Geochemistry of Dolomite: The State of the Art; SEPM Society for Sedimentary Geology: Tulsa, OK, USA, 1980.

61. Rosenberg, P.; Holland, H. Calcite-dolomite-magnesite stability relations in solutions at elevated temperatures. Science 1964, 145, 700-701. [CrossRef] [PubMed]

62. Nancollas, G.H.; Reddy, M.M. The crystallization of calcium carbonate. II. Calcite growth mechanism. J. Colloid Interface Sci. 1971, 37, 824-830. [CrossRef]

63. Wiechers, H.; Sturrock, P.; Marais, G. Calcium carbonate crystallization kinetics. Water Res. 1975, 9, 835-845. [CrossRef]

64. Kazmierczak, T.; Tomson, M.; Nancollas, G. Crystal growth of calcium carbonate. A controlled composition kinetic study. J. Phys. Chem. 1982, 86, 103-107. [CrossRef]

65. Arvidson, R.S.; Mackenzie, F.T. The dolomite problem; control of precipitation kinetics by temperature and saturation state. Am. J. Sci. 1999, 299, 257-288. [CrossRef]

66. Arvidson, R.S.; Mackenzie, F.T. Tentative kinetic model for dolomite precipitation rate and its application to dolomite distribution. Aquat. Geochem. 1997, 2, 273-298. [CrossRef]

67. Gregg, J.M.; Bish, D.L.; Kaczmarek, S.E.; Machel, H.G. Mineralogy, nucleation and growth of dolomite in the laboratory and sedimentary environment: A review. Sedimentology 2015, 62, 1749-1769. [CrossRef]

68. Mucci, A.; Morse, J.W. The incorporation of $\mathrm{Mg}^{2+}$ and $\mathrm{Sr}^{2+}$ into calcite overgrowths: Influences of growth rate and solution composition. Geochim. Cosmochim. Acta 1983, 47, 217-233. [CrossRef]

69. Mucci, A. Growth kinetics and composition of magnesian calcite overgrowths precipitated from seawater: Quantitative influence of orthophosphate ions. Geochim. Cosmochim. Acta 1986, 50, 2255-2265. [CrossRef]

70. Hartley, G.; Mucci, A. The influence of $\mathrm{P}_{\mathrm{CO} 2}$ on the partitioning of magnesium in calcite overgrowths precipitated from artificial seawater at $25^{\circ}$ and $1 \mathrm{~atm}$ total pressure. Geochim. Cosmochim. Acta 1996, 60, 315-324. [CrossRef]

71. Huang, Y.; Fairchild, I.J. Partitioning of $\mathrm{Sr}^{2+}$ and $\mathrm{Mg}^{2+}$ into calcite under karst-analogue experimental conditions. Geochim. Cosmochim. Acta 2001, 65, 47-62. [CrossRef]

72. Katz, A. The interaction of magnesium with calcite during crystal growth at $25-90{ }^{\circ} \mathrm{C}$ and one atmosphere. Geochim. Cosmochim. Acta 1973, 37, 1563-1586. [CrossRef]

73. Berner, R. The role of magnesium in the crystal growth of calcite and aragonite from sea water. Geochim. Cosmochim. Acta 1975, 39, 489-504. [CrossRef]

74. Oomori, T.; Kaneshima, H.; Maezato, Y.; Kitano, Y. Distribution coefficient of $\mathrm{Mg}^{2+}$ ions between calcite and solution at $10-50{ }^{\circ} \mathrm{C}$. Mar. Chem. 1987, 20, 327-336. [CrossRef] 